Ramkumar Dhanasekaran $₫$ Gautam Dilip Mehta $\odot$ Aruna Parameswari $\odot$

\title{
A Prospective Randomized Comparative Study between Baska Mask, Proseal LMA and I Gel During Positive Pressure Ventilation in Laparoscopic Cholecystectomy
}

\author{
Laparoskopik Kolesistektomide Pozitif Basınçlı \\ Ventilasyon Sirasında Baska Mask, Proseal LMA \\ ve I Gel ile Prospektif Randomize Karşılaştırmalı \\ Bir Çalışma
}

\begin{abstract}
Objective: Supraglottic airway devices with facility for gastric suction such as Proseal LMA and I gel have been successfully used for positive pressure ventilation in laparoscopic surgeries. Baska mask, a novel device with many unique features such as self-sealing membranous cuff and effective sump drainage system was designed in such a way that the perilaryngeal seal increases incrementally with increasing airway pressures. But Baska mask was not extensively evaluated to validate its use in laparoscopic surgeries. The efficiency of Baska mask (B), Proseal LMA (P) and I $\mathrm{Gel}$ (I) are compared during positive pressure ventilation in laparoscopic cholecystectomy.

Methods: Ninety patients of ASA physical status I-II planned for laparoscopic cholecystectomy were randomized into three groups $(B, I, P)$ of 30 each. The study was proceeded with $88(B-30$, $1-29, P-29)$ patients. Oropharyngeal leak pressure, insertion time, effective airway time and airway morbidity were assessed and compared between the three groups. Mean, standard deviation, paired sample t-test, one way ANOVA with Tukey's Post-Hoc test was used.

Results: The oropharyngeal leak pressure at insertion time was $38.33 \pm 4.353 \mathrm{~cm}$ of $\mathrm{H}_{2} \mathrm{O}$ for group $B, 30.57 \pm 2.174 \mathrm{~cm}$ of $\mathrm{H}_{2} \mathrm{O}$ for group $I, 29.36 \pm 2.706 \mathrm{~cm}$ of $\mathrm{H} 2 \mathrm{O}$ for group $P$. The leak pressure was statistically significant between group $B$ and other groups.

Conclusions: Baska mask provided higher oropharyngeal leak pressure in comparison to other two supraglottic devices.
\end{abstract}

Keywords: Baska mask, Proseal LMA, I Gel, oropharyngeal leak pressure, laparoscopic cholecystectomy

Öz

Amaç: Proseal LMA ve I gel gibi gastrik aspirasyon avantajı olan supraglottik hava yolu araçları, laparoskopik ameliyatlarda pozitif basınçı ventilasyonda başarıyla kullanılmaktadır. Kendiliğinden yerleşen membranöz cuff ve etkin sıvı drenaj sistemi gibi pek çok benzersiz özelliğe sahip yeni bir cihaz olan Baska mask, perilarengeal yerleşme basıncının, artan hava yolu basınçları ile aşamalı olarak artacağı şekilde tasarlanmıştır. Ancak, Baska maskın, laparoskopik ameliyatlarda kullanımı kapsamlı olarak araştırılmamıştır. Laparoskopik kolesistektomide pozitif basınçlı ventilasyon sırasında Baska mask (B), Proseal LMA (P) ve I Gel (I)'in etkinliği karşılaştırıldı.

Yöntem: Laparoskopik kolesistektomi planlanan ASA I-II 90 hasta, üç gruba $(B, I, P)$ randomize edildi. Çalışma 88 (B-30, I-29, P-29) hasta ile sürdürüldü. Orofarengeal kaçak basıncI, yerleştirme zamanı, etkin hava yolu zamanı ve hava yolu morbiditesi değerlendirildi ve üç grup karşılaştırıldı. istatistiksel analizde; ortalama, standart sapma, paired sample t-testi, Tukey Post-Hoc testi ile tek yönlü ANOVA kullanıldı.

Bulgular: Yerleştirme sırasında orofarengeal kaçak basıncı, B grubunda $38.33 \pm 4.353 \mathrm{CmH}_{2} \mathrm{O}, \mathrm{I}$ grubunda $30.57 \pm 2.174 \mathrm{cmH}_{2} \mathrm{O}, P$ grubunda $29.36 \pm 2.706 \mathrm{cmH}_{2} \mathrm{O}$ idi. Kaçak basıncı, $B$ grubu ve diğer gruplar arasında istatistiksel olarak anlamlıydı.

Sonuç: Baska mask, diğer iki supraglottik araç ile karşılaştırıldığında daha yüksek orofaringeal kaçak basıncı sağladı. Bu çalışmada kullanılan üç farklı ikinci kuşak supraglottik hava yolu aracı arasında, Baska mask, yüksek orofarengeal kaçak basıncı ile yeterli ventilasyonun sağlanmasında daha etkin bulunmuştur.

Anahtar kelimeler: Baska mask, Proseal LMA, I Gel, orofarengeal kaçak basıncı, laparoskopik kolesistektomi

(C) Telif hakkı Anestezi ve Reanimasyon Uzmanları Derneği. Logos Tıp Yayıncılık tarafindan yayınlanmaktadır. Bu dergide yayınlanan bütün makaleler Creative Commons Atff-GayriTicari 4.0 Uluslararası Lisansı ile lisanslanmıştır.

(c) Copyright Anesthesiology and Reanimation Specialists' Society. This journal published by Logos Medical Publishing. Licenced by Creative Commons Attribution-NonCommercial 4.0 International (CC BY-NC 4.0)
Alındığı tarih: 18.02.2019

Kabul tarihi: 25.03.2019

Yayın tarihi: 30.04 .2019

Atıf vermek için: Dhanasekaran, Mehta GD, Parameswari A. A Prospective Randomized Comparative Study between Baska Mask, Proseal LMA and I Gel During Positive Pressure Ventilation in Laparoscopic Cholecystectomy. JARSS 2019;27(2):106-11.

Ramkumar Dhanasekaran No 1, Ramachandra Nagar, Porur, 600116 Chennai - India docram82@gmail.com ORCID: 0000-0001-6112-2595

G.D. Mehta 0000-0001-9292-4179 A. Parameswari 0000-0002-1280-5047

Department of Anesthesiology and Pain Medicine, Sri Ramachandra Institute of Higher Education and Research, Porur, Chennai India 
R. Dhanasekaran et al. A Prospective Randomized Comparative Study between Baska Mask, Proseal LMA and I Gel During Positive Pressure Ventilation in Laparoscopic Cholecystectomy

\section{INTRODUCTION}

Laparoscopic cholecystectomy has become a standard and less invasive technique for cholecystectomy surgeries in gall bladder diseases ${ }^{(1,2)}$. Although tracheal intubation is considered as an ideal approach, it has disadvantages like raised respiratory and hemodynamic responses during intubation, pneumoperitoneum and extubation ${ }^{(3-9)}$. However, supraglottic airway devices (SAD) with facility for gastric suction such as Proseal LMA and I gel have been successfully used in laparoscopic cholecystectomy ${ }^{(10-16)}$. Initial experience with Baska mask has demonstrated it to be a suitable device ${ }^{(17,18)}$ and there are only limited literature comparing these devices, so we decided to assess the efficiencies of Baska mask, I gel and Proseal LMA during laparoscopic cholecystectomy.

\section{MATERIAL and METHODS}

After obtaining approval from the hospital ethics committee and written informed consent from the patients, this prospective randomized comparative study was done in 90 ASA (American Society of Anesthesiology) physical status grade I-II patients, aged 18-60 years scheduled for elective laparoscopic cholecystectomy, divided into 3 groups of 30 patients each. The primary objective of this study was to compare the oropharyngeal leak pressure between the three devices. The secondary objectives were to compare the insertion time, number of attempts, and airway-related complications of these three devices in patients.

Based on the pilot study with oropharyngeal leak pressure as the primary outcome with 5 cases in each group to find an effect size of $3 \mathrm{cmH}_{2} \mathrm{O}$ with power of $80 \%$ and an alpha error of 0.05 , the calculated sample size was 28 cases in each group. Considering the possibility of dropouts from the study, we decided to include 90 patients in the study. Exclusion criteria were patient's refusal, ASA PS III and above, predicted difficult airway as per Benumof's 11 parameter analysis, mouth opening of $<2.5 \mathrm{~cm}$, patients at increased risk of aspiration of gastric contents including gastro-esophageal reflux disorders, conversion to open surgery for various reasons, restrictive and obstructive lung disease and $\mathrm{BMI}>30 \mathrm{~kg} \cdot \mathrm{m}^{-2}$. Randomization was done using com- puter generated numbers into three groups of 30 each in Group B-Baska mask (Baska Versatile Laryngeal Mask (BVLM) Pty Ltd, Australia), Group I - I gel (Intersurgical Ltd, UK) and Group P-Proseal LMA (PLMA) (Teleflex Medical Europe Ltd, Ireland).

The pre-anesthetic visit of the patient was performed by an anesthesiologist not involved in the study. Size selection was based on the manufacturer's recommendation and weight-based estimate ${ }^{(17-19)}$. A standard anesthesia technique was followed. On arrival in operating theatre, the patients were connected to standard monitoring devices. After preoxygenation and administration of fentanyl $2 \mu \mathrm{g} \mathrm{kg}^{-1}$, induction of anaesthesia was done using propofol 2 $\mathrm{mg} \mathrm{kg}^{-1}$ and vecuronium $0.1 \mathrm{mg} \mathrm{kg}^{-1}$ was given. Anesthesia was considered adequate for SAD insertion when the patient was unresponsive, had lost the eyelash reflex, and did not respond to anterior jaw thrust ${ }^{(18)}$. Anesthesia was maintained using sevoflurane $1.5-2.0 \%$ in oxygen $40 \%$ and air. Analgesia was achieved with additional intermittent boluses of 0.5 $\mu \mathrm{g} \mathrm{kg}{ }^{-1}$ fentanyl every one hour with a margin of not less than 20 minutes prior to extubation and infiltration of the surgical wound with $0.25 \%$ bupivacaine. All patients received intravenous paracetamol $1 \mathrm{~g}$ intra-operatively. All the devices were inserted by an anesthesiologist who had sufficient experience in the use of all three devices.

The Proseal LMA was introduced by the standard technique without using the introducer and the cuff was inflated with air according to the size used (19). The I gel and Baska mask are cuffless devices not requiring the same procedure.

The patency of the airway was ascertained and the SAD was connected to the breathing circuit and fixed. An initial assessment of airway patency and the ability to ventilate the lungs was made by gently squeezing the reservoir bag and observing the amplitude of end-tidal carbon dioxide waveforms and the presence of chest movements. Volume-controlled ventilation was used with the tidal volume of 8-10 $\mathrm{mL} \mathrm{kg}-1$ and the respiratory rate was 10 to 16 per minute to maintain $\mathrm{EtCO}_{2}$ between $35-45 \mathrm{cmH}_{2} \mathrm{O}$. A lubricated orogastric tube was inserted through the gastric channels into the stomach to confirm the correct placement. 
Oropharyngeal leak pressure was determined following mask insertion the supine position before development of pneumoperitoneum and at $30 \mathrm{~min}$ of surgery in the supine position with pneumoperitoneum by closing the expiratory valve of the circle system at a fixed gas flow of $3 \mathrm{~L} \mathrm{~min}^{-1}$ and noting the airway pressure when the equilibrium was reached. A maximum pressure of $40 \mathrm{cmH}_{2} \mathrm{O}$ was allowed during measurement ${ }^{(18)}$. The insertion time was taken as the time between picking-up the prepared device and its successful placement ${ }^{(18)}$. The effective airway time is the time between picking-up the prepared device and obtaining the first capnographic trace. The success of insertion was assessed by the number of insertion attempts (counted as an attempt when the SAD is taken in and out of the mouth). Postoperative airway morbidity such as sore throat, dysphagia, dysphonia were graded as none, mild, moderate, or severe at $4^{\text {th }}$ hour postoperatively ${ }^{(18)}$. Intra-operative complications were recorded. If an adequate capnogram and ventilation were not achieved after two insertion attempts, endotracheal tube was used and the patient was excluded from the study. The SAD was removed when protective reflexes returned to normal after reversal of neuromuscular blockade.

\section{Statistical Analysis}

The collected data were analysed with IBM.SPSS statistics software 23.0 Version. Descriptive statistics, and frequency analysis were used for categorical variables and the mean, standard deviation were used for continuous variables. To find the significant difference between the bivariate samples in paired groups, the paired sample t-test was used. In order to compare more than two groups in terms of numerical variables, the one way ANOVA with Tukey's Post-Hoc test was used. To find the significance in categorical data, chi-square test was used. In all the above statistical tools, the probability value $p<0.05$ was considered as the level of significance.

\section{RESULTS}

Ninety patients were randomized into three groups as $\mathrm{B}, \mathrm{I}, \mathrm{P}$, among which 2 patients were excluded from study as laparoscopy was converted to open surgery (Figure 1). The final study groups included 88 patients $(B=30, I=29, P=29)$. The age, gender distribution, BMI and the ASA physical status of the patients were comparable (Table I and II). The insertion time for Group B was $11.47 \pm 3.2$ minutes (min), Group I - $12.50 \pm 2.8(\mathrm{~min})$ and for group P it was $14.07 \pm 3.6$ ( $\mathrm{min}$ ). Intergroup difference as for insertion time was not statistically significant. The effective airway time, the maximum $\mathrm{ETCO}_{2}$ and the duration of anesthesia were not also statistically significant between the groups (Table II).

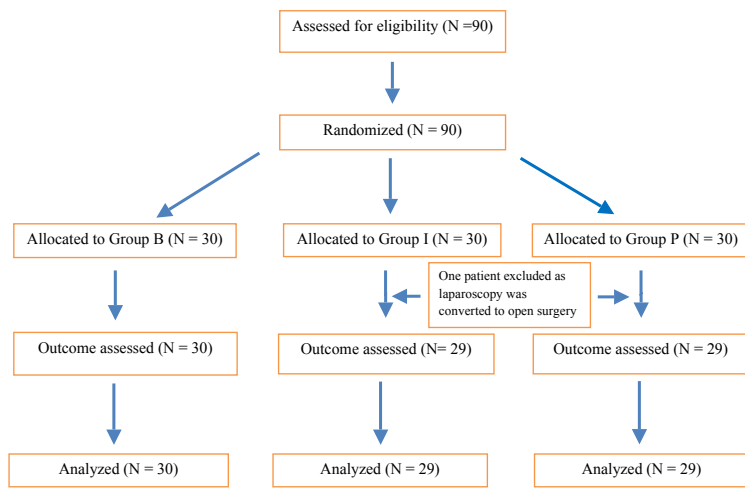

Figure 1. Study flowchart

Table I. Gender distribution and ASA physical status among groups

\begin{tabular}{llccccc}
\hline \multicolumn{2}{l}{ Parameters } & B & I & P & Total & p value \\
\hline \multirow{2}{*}{ Sex } & Female & 22 & 22 & 20 & 64 & 0.41 \\
\multirow{4}{*}{ ASA Class } & Male & 8 & 7 & 9 & 22 & \\
& I & 18 & 21 & 20 & 59 & 0.83 \\
& II & 12 & 8 & 9 & 29 &
\end{tabular}

$B=$ Baska mask $I=I$ gel,$P=$ Proseal $L M A, A S A=$ American Society of Anesthesiologist.

Oropharyngeal leak pressure during insertion time and 30 min after insertion was analysed within the group and between the groups. The leak pressure at insertion time was $38.33 \pm 4.4 \mathrm{~cm}$ of $\mathrm{H}_{2} 0$ for Group B, $30.57 \pm 2.2 \mathrm{~cm}$ of $\mathrm{H}_{2} \mathrm{O}$ for Group I, $29.36 \pm 2.7 \mathrm{~cm}$ of $\mathrm{H}_{2} \mathrm{O}$ for Group P. The $\mathrm{p}$ value revealed statistical significance between Group B and the other two groups, but $p$ value obtained for Group I and Group P was not statistically significant. The leak pressure after 30 minutes of insertion was $40.00 \pm 2.4 \mathrm{~cm}$ of $\mathrm{H}_{2} \mathrm{O}$ for Group B, $35.14 \pm 3.2 \mathrm{~cm}$ of $\mathrm{H}_{2} \mathrm{O}$ for Group I, $34.36 \pm 1.3 \mathrm{~cm}$ of $\mathrm{H}_{2} \mathrm{O}$ for Group P. The $\mathrm{p}$ value was significant for Group B in comparison with other two groups, but insignificant for Groups I and P (Table II). The oropharyngeal leak pressure at insertion and at 
R. Dhanasekaran et al. A Prospective Randomized Comparative Study between Baska Mask, Proseal LMA and I Gel During Positive Pressure Ventilation in Laparoscopic Cholecystectomy

30 minutes for Groups I and P was statistically significant when compared to Baska mask (Table III).

Table II. Patient characteristics and SAD placement parameters

\begin{tabular}{|c|c|c|c|c|c|}
\hline S.No & $\begin{array}{l}\text { Patient } \\
\text { characteristics }\end{array}$ & Group & $\mathrm{n}$ & Mean \pm SD & $p$ value \\
\hline \multirow[t]{3}{*}{1} & \multirow[t]{3}{*}{ Age (Years) } & B & 30 & $47.67 \pm 8.2$ & \\
\hline & & 1 & 29 & $47.71 \pm 9.0$ & 0.951 \\
\hline & & $P$ & 29 & $46.79 \pm 9.2$ & \\
\hline \multirow[t]{3}{*}{2} & \multirow[t]{3}{*}{ Height (cm) } & B & 30 & $155.20 \pm 6.0$ & \\
\hline & & 1 & 29 & $160.86 \pm 7.4$ & 0.098 \\
\hline & & $P$ & 29 & $159.14 \pm 7.8$ & \\
\hline \multirow[t]{3}{*}{3} & \multirow[t]{3}{*}{ BMI $\left(\mathrm{Kg} \mathrm{m}^{-2}\right)$} & B & 30 & $24.113 \pm 2.5$ & \\
\hline & & 1 & 29 & $25.600 \pm 3.1$ & 0.173 \\
\hline & & $\mathrm{P}$ & 29 & $25.779 \pm 1.9$ & \\
\hline \multirow[t]{3}{*}{4} & \multirow{3}{*}{$\begin{array}{l}\text { Insertion Time } \\
\text { (Seconds) }\end{array}$} & B & 30 & $11.47 \pm 3.2$ & \\
\hline & & I & 29 & $12.50 \pm 2.8$ & 0.105 \\
\hline & & $P$ & 29 & $14.07 \pm 3.6$ & \\
\hline \multirow[t]{3}{*}{5} & \multirow{3}{*}{$\begin{array}{l}\text { Effective Airway Time } \\
\text { (seconds) }\end{array}$} & B & 30 & $20.00 \pm 2.5$ & \\
\hline & & 1 & 29 & $20.14 \pm 3.7$ & 0.808 \\
\hline & & $\mathrm{P}$ & 29 & $19.71 \pm 2.8$ & \\
\hline \multirow[t]{3}{*}{6} & \multirow{3}{*}{$\begin{array}{l}\text { Maximum } \mathrm{ETCO}_{2} \\
(\mathrm{~mm} \mathrm{Hg})\end{array}$} & B & 30 & $36.00 \pm 1.3$ & \\
\hline & & I & 29 & $35.57 \pm 1.7$ & 0.664 \\
\hline & & $P$ & 29 & $35.57 \pm 1.3$ & \\
\hline \multirow[t]{3}{*}{7} & Duration of & B & 30 & $95.07 \pm 39.6$ & \\
\hline & \multirow[t]{2}{*}{ Anaesthesia (minutes) } & I & 29 & $127.50 \pm 50.5$ & 0.101 \\
\hline & & $P$ & 29 & $101.00 \pm 33.9$ & \\
\hline \multirow[t]{6}{*}{8} & \multirow{3}{*}{$\begin{array}{l}\text { Oropharyngeal Leak } \\
\text { pressure at insertion } \\
\text { time }\left(\mathrm{cm} \text { of } \mathrm{H}_{2} \mathrm{O}\right)\end{array}$} & B & 30 & $38.33 \pm 4.4$ & \\
\hline & & I & 29 & $30.57 \pm 2.2$ & 0.04 \\
\hline & & $P$ & 29 & $29.36 \pm 2.7$ & \\
\hline & Oropharyngeal Leak & B & 30 & $40.00 \pm 2.4$ & \\
\hline & pressure at 30 & I & 29 & $35.14 \pm 3.2$ & 0.04 \\
\hline & $\begin{array}{l}\text { minutes of insertion } \\
\left(\mathrm{cm} \text { of } \mathrm{H}_{2} \mathrm{O}\right)\end{array}$ & $P$ & 29 & $34.36 \pm 1.3$ & \\
\hline
\end{tabular}

$B=$ Baska mask, $I=I$ gel,$P=$ Proseal $L M A, S D=$ Standard Deviation, $B M I=B o d y$ Mass Index, $\mathrm{ETCO}_{2}=$ End Tidal Carbon dioxide, $\mathrm{SPO}_{2}=$ Oxygen saturation.

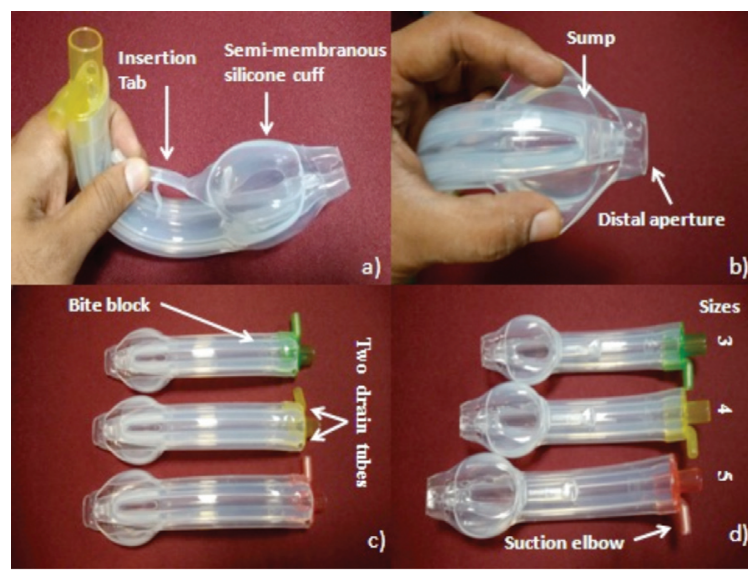

Figure 2. Baska mask. a) Insertion tab for manually curving the tab for easy insertion and self sealing variable pressure semimembranous silicone cuff, b) Sump for easy drainage of gastric and throat contents, c) Two drain tubes on either side of ventilating tube with bite block, d) Different sizes of Baska mask with detachable suction elbow for attachment of suction tubing
Table III. Within group comparison of oropharyngeal leak pressure.

\begin{tabular}{lllccc}
\hline S.No & Group (n) & $\begin{array}{c}\text { At insertion time } \\
\left(\mathbf{c m H}_{\mathbf{2}} \mathbf{O}\right)\end{array}$ & $\begin{array}{c}\text { After } \mathbf{3 0} \mathbf{m i n} \\
\left(\mathbf{c m H}_{\mathbf{2}} \mathbf{O}\right)\end{array}$ & p value \\
\hline 1 & $\mathrm{~B}$ & $(30)$ & $38.33 \pm 4.4$ & $40.00 \pm 2.4$ & 0.07 \\
2 & $\mathrm{I}$ & $(29)$ & $30.57 \pm 2.2$ & $35.14 \pm 3.2$ & 0.0005 \\
3 & $\mathrm{P}$ & $(29)$ & $29.36 \pm 2.7$ & $34.36 \pm 1.3$ & 0.0005 \\
\hline
\end{tabular}

$B=$ Baska mask, $I=$ lgel, $P=$ Proseal $L M A$

\section{DISCUSSION}

This study compared the use of three supraglottic devices in laparoscopic cholecystectomy surgery. The demographic profile and ASA physical status of the subjects in the three groups [B, I, P] were comparable. In our study, Baska mask had the quickest insertion time (11.47 \pm 3.2 seconds) when compared to the Proseal LMA (14.07 \pm 3.6 seconds) and I gel (12.50 \pm 2.79 seconds) (Table II), though the intergroup difference was not statistically significant. This may be due to its anatomical curvature which does not require manual opening of mouth to insert, its non inflatable cuff, shorter time to inflate the cuff and needless volume adjustment as required in PLMA. This demonstrates that a short learning curve is sufficient for the placement of Baska mask. Although statistically non-significant, effective airway time was shorter in PLMA group which would probably attributed to long experience as also reported in another study (24). Two male patients in the Baska mask, and one male patient in the Proseal group required two insertion attempts but none of the patients required endotracheal intubations due to failure of device insertion. Oxygenation and ventilation were optimal in all patients throughout the surgery. The end-tidal carbon dioxide levels and duration of anesthesia were comparable in all the three groups (Table II).

The primary objective of this study is to assess the oropharyngeal leak pressure among the three supraglottic devices used in the study. This was assessed during and 30 minutes after insertion in all the subjects. Oropharyngeal leak pressure reveals the degree of airway protection, feasibility for using in positive pressure ventilation and success of the device placement ${ }^{(25)}$. High leak pressure was provided by Baska mask $\left(38.33 \pm 4.4 \mathrm{cmH}_{2} \mathrm{O}\right)$ at insertion time was 
comparable even 30 minutes after insertion $\left(40.00 \pm 2.4 \mathrm{~cm}\right.$ of $\left.\mathrm{H}_{2} \mathrm{O}\right)$ which was measured during laparoscopy, and statistically significant in comparison to other devices. Al Rawahi et al. (26) compared the Baska mask with the Proseal LMA and found that the sealing pressure was significantly higher in the Baska group ( $30 \pm 9$ vs $24 \pm 6 \mathrm{~cm}$ of $\mathrm{H}_{2} \mathrm{O}$ ). Higher sealing pressure achieved with Baska mask over PLMA was also shown in other studies ${ }^{(18,19,26,31)}$. In this study Igel and PLMA were comparable in terms of oropharyngeal leak pressure.

The inflatable cuff of SADs has often been held responsible for the device-related complications or laryngopharyngeal morbidity (LPM) ${ }^{(32)}$. However, in this study, we did not observe any significant dysphagia or dysphonia at extubation and at 4 hours postoperatively between the three devices. However, 8 patients in PLMA group, 2 each in BM and I gel group had mild sore throat at 4 hours postoperatively, which probably can be attributed to cuff pressure in Proseal LMA patients.

The sealing pressure serves as an index of airway and respiratory mechanics ${ }^{(33)}$. Hence high oropharyngeal leak pressures are necessary to deliver the required increased peak airway pressures without the fear of leak, gastric insufflation and resultant pulmonary aspiration. Despite these issues with pneumoperitoneum, in our study there were no problems of hypoventilation, leak, gastric distension, desaturation and aspiration in any of the groups. Amongst the three groups, Baska mask has higher oropharyngeal leak pressure when compared to the other two devices, proving that Baska Mask is superior to other second generation SADs in terms of higher oropharyngeal leak pressure. Our study had a few limitations. Obese patients and those with restrictive lung disease were not included in the study, which may be evaluated in future for further validation.

\section{CONCLUSION}

In this study, Baska mask showed higher mean oropharyngeal leak pressure compared to the other two supraglottic devices, while mean oropharyngeal leak pressures of the other two devices were comparable.
Ethics Committee Approval: Recelved from SRI Ramachandra Institute of Higher Education and Research Deemed to be University (CSP-MED/16) AUG/30/129).

Conflict of Interest: None.

Funding: None.

Informed Consent: The patient's consent was obtained.

\section{REFERENCES}

1. Medeiros AC, Araújo-Filho I, Carvalho MD, de Paiva Medeiros VF, de Azevedo ÍM, Dantas Filho AM. Laparoscopic versus open cholecystectomy: complications and cost. Journal of Surgical and Clinical Research. 2013;3:49-58. https://doi.org/10.20398/jscr.v3i2.3567

2. Sharma KC, Brandstetter RD, Brensilver JM, Jung LD. Cardiopulmonary physiology and pathophysiology as a consequence of laparoscopic surgery. Chest. 1996;110:810-5. https://doi.org/10.1378/chest.110.3.810

3. Diebel LN, Wilson RF, Dulchavsky SA, Saxe J. Effect of increased intra-abdominal pressure on hepatic arterial, portal venous, and hepatic microcirculatory blood flow. The Journal of Trauma. 1992;33:279-82. https://doi.org/10.1097/00005373-199208000-00019

4. Hashikura $Y$, Kawasaki S, Munakata Y, Hashimoto S, Hayashi K, Makuuchi M. Effects of peritoneal insufflation on hepatic and renal blood flow. Surgical Endoscopy. 1994;8:759-61. https://doi.org/10.1007/BF00593435

5. Hong JY, Chung KH, Lee YJ. The changes of ventilatory parameters in laparoscopic cholecystectomy. Yonsei Medical Journal. 1999;40:307-12. https://doi.org/10.3349/ymj.1999.40.4.307

6. Meininger D, Byhahn C, Mierdl S, Westphal K, Zwissler B. Positive end-expiratory pressure improves arterial oxygenation during prolonged pneumoperitoneum. Acta Anaesthesiologica Scandinavica. 2005;49:778-83. https://doi.org/10.1111/j.1399-6576.2005.00713.x

7. Hazebroek EJ, Haitsma JJ, Lachmann B, Bonjer HJ. Mechanical ventilation with positive end-expiratory pressure preserves arterial oxygenation during prolonged pneumoperitoneum. Surgical Endoscopy. 2002;16:685-9. https://doi.org/10.1007/s00464-001-8174-y

8. Ogunnaike BO, Jones SB, Jones DB, Provost D, Whitten CW. Anesthetic considerations for bariatric surgery. Anesthesia \& Analgesia. 2002;95:1793-805. https://doi.org/10.1097/00000539-200212000-00061

9. Mercat A, Graïni L, Teboul JL, Lenique F, Richard C. Cardiorespiratory effects of pressure-controlled ventilation with and without inverse ratio in the adult respiratory distress syndrome. Chest. 1993;104:871-5. https://doi.org/10.1378/chest.104.3.871

10. Park SY, Rim JC, Kim H, Lee JH, Chung CJ. Comparison of I-gel and LMA Supreme during laparoscopic cholecystectomy. Korean Journal of Anesthesiology. 
2015;68:455-61. https://doi.org/10.4097/kjae.2015.68.5.455

11. Howes B, Cook T. Supraglottic airway devices: recent advances. Contin Educ Anaesth Crit Care Pain. 2010;11:56-61.

https://doi.org/10.1093/bjaceaccp/mkq058

12. Ramachandran SK, Kumar AM. Supraglottic Airway Devices Discussion. Respiratory Care. 2014;59:920-32. https://doi.org/10.4187/respcare.02976

13. Cook TM. Novel airway devices: spoilt for choice? Anaesthesia. 2003;58:107-10. https://doi.org/10.1046/j.1365-2044.2003.03047.x

14. Maltby JR, Beriault MT, Watson NC, Liepert D, Fick GH. The LMA-ProSeal ${ }^{\mathrm{TM}}$ is an effective alternative to tracheal intubation for laparoscopic cholecystectomy. Canadian Journal of Anesthesia. 2002;49:857-62. https://doi.org/10.1007/BF03017420

15. Badheka JP, Jadliwala RM, Chhaya VA, Parmar VS, Vasani A, Rajyaguru AM. I-gel as an alternative to endotracheal tube in adult laparoscopic surgeries: A comparative study. Journal of Minimal Access Surgery. 2015;11:251. https://doi.org/10.4103/0972-9941.140210

16. Chaudhary UK, Mahajan SR, Mahajan M, Sharma C, Sharma M. A comparative analysis of the baska mask versus I-gel for general anesthesia in surgical patients undergoing laparoscopic cholecystectomy. Acta Medica International. 2018;5:69-73. https://doi.org/10.4103/ami.ami_41_18

17. Baska K, Baska M. Baska Mask- The new generation supraglottic airway with high volume suction clearance; Instructions for use. Available on http://www.baskamask.com.au/baskamasksizes.html

18. Van Zundert T, Gatt S. The Baska Mask - A new concept in self-sealing membrane cuff extraglottic airway devices using a sump and two gastric drains: A critical evaluation. J Obstet Anaesth Crit Care. 2012;2:23-30. https://doi.org/10.4103/2249-4472.99313

19. Sharma B, Sehgal R, Sahai C, Sood J. PLMA vs. I-gel: A comparative evaluation of respiratory mechanics in laparoscopic cholecystectomy. J Anaesthesiol Clin Pharmacol. 2010;26:451-7.

20. Teoh WHL, Lee KM, Suhitharan T, Yahaya Z, Teo MM, Sia ATH. Comparison of the LMA Supreme vs the i-gel ${ }^{\mathrm{TM}}$ in paralysed patients undergoing gynaecological laparoscopic surgery with controlled ventilation. Anaesthesia. 2010;65:1173-9. https://doi.org/10.1111/j.1365-2044.2010.06534.x

21. Singh A, Bhalotra AR, Anand R. A comparative evaluation of ProSeal laryngeal mask airway, l-gel and Supreme laryngeal mask airway in adult patients undergoing elective surgery: A randomised trial. Indian Journal of Anaesthesia. 2018;62:858-64. https://doi.org/10.4103/ija.IJA_153_18

22. Liew GH, Yu ED, Shah SS, Kothandan H. Comparison of the clinical performance of i-gel, LMA Supreme and LMA ProSeal in elective surgery. Singapore Medical
Journal 2016;57:432-7.

https://doi.org/10.11622/smedj.2016133

23. Henlin T, Sotak M, Kovaricek P, Tyll T, Balcarek L, Michalek P. Comparison of five 2nd-generation supraglottic airway devices for airway management performed by novice military operators. BioMed Research International 2015;2015. https://doi.org/10.1155/2015/201898

24. Verma S, Sharma SP. Effectiveness of Proseal laryngeal mask airway and laryngeal tube suction in elective non-laparoscopic surgeries of up to ninety minutes duration: A prospective, randomized study. Journal of Anaesthesiology, Clinical Pharmacology. 2018;34:58-61.

25. Gill RK, Tarat A, Pathak D, Dutta S. Comparative study of two laryngeal mask airways: Proseal laryngeal mask airway and supreme laryngeal mask airway in anesthetized paralyzed adults undergoing elective surgery. Anesthesia, Essays and Researches. 2017;11:23-7. https://doi.org/10.4103/0259-1162.177184

26. Al-Rawahi SA, Aziz H, Malik AM, Khan RM, Kaul N. A comparative analysis of the Baska mask vs Proseal laryngeal mask for general anesthesia with IPPV. Anaesth Pain \& Intensive Care. 2013;17:233-6.

27. Alexiev V, Salim A, Kevin LG, Laffey JG. An observational study of the Baska ${ }^{\circledR}$ mask: a novel supraglottic airway. Anaesthesia. 2012;67:640-5. https://doi.org/10.1111/j.1365-2044.2012.07140.x

28. López AM, Mu-oz-Rojas G, Fontanals M, de San José I, Hermoso A, Valero R. Clinical evaluation of the Baska Mask ${ }^{\circledR}$ laryngeal mask in adult patients in ambulatory surgery. Revista Espa-ola de Anestesiología y Reanimación (English Edition). 2015;62:551-6. https://doi.org/10.1016/j.redare.2015.07.002

29. Font MC, García-Aguado R, Pascual Jú. Funduplicatura de Nissen Laparoscópica con mascarilla laríngea Baska Mask $^{\circledR}$. Revista Espa-ola de Anestesiología y Reanimación. 2016;63:599-603. https://doi.org/10.1016/j.redar.2016.03.010

30. Aziz RA, Osman YM. Comparison of I-gel with Baska Mask Airway for Controlled Ventilation in Obese Patients Undergoing Ambulatory Surgery: A Prospective Randomized Trial. Journal of Anesthesiology. 2017;5:2935. https://doi.org/10.11648/j.ja.20170504.12

31. Almeida G, Costa AC, Machado HS. Supraglottic airway devices: a review in a new era of airway management. J Anesth Clin Res. 2016;7:2. https://doi.org/10.4172/2155-6148.1000647

32. Lai CJ, Liu CM, Wu CY, Tsai FF, Tseng PH, Fan SZ. I-Gel is a suitable alternative to endotracheal tubes in the laparoscopic pneumoperitoneum and trendelenburg position. BMC Anesthesiology. 2017;17:3. https://doi.org/10.1186/s12871-016-0291-1

33. Maharjan SK. I-gel for positive pressure ventilation. Journal of the Nepal Medical Association 2013;52:255-9.

https://doi.org/10.31729/jnma.571 